\title{
The Impact of social infrastructures on economic growth of Sub-Saharan Africa: implications for sustainable economic growth
}

\author{
Ezebuilo R. Ukwueze, Oliver E. Ogbonna, Ozoemena S. Nwodo, \\ \& Chinasa E. Urama \\ Department of Economics, University of Nigeria, \\ Nsukka, Nigeria. \\ Email: oliver.ogbonna@unn.edu.ng
}

\begin{abstract}
Background: Economic growth in sub-Saharan Africa has consistently remained the least when compared to any other region in the world. Countries in the region have received a lot of grants in form of aids to boost their capital accumulation; yet there is slow growth in most parts of the region. Many countries have implemented the World Bank and IMF suggested policies; and majority of the countries have adopted democratic political system. Yet growth in the region has remained very low. It then becomes pertinent to identify the causes of the low economic growth pattern in sub-Saharan Africa (SSA). The objective of this study, therefore, is to determine the impact of social infrastructure on economic growth of sub-Saharan Africa.

Data and methods: The data for this study were 200I-2017 time-series data sourced from World Governance Indicators (WGI) and World Development Indicators (WDI). The standard panel data of fixed effect (FE) and random effect (RE) were employed in the analysis of the data, while Hausman test results guided the final choice of fixed effect estimation.

Findings: The results show that corruption is statistically and significantly affecting economic growth of sub-Saharan African (SSA) countries. This means that control of corruption will help boost the economies in the region as low corruption is a prerequisite for economic recovery and sustainable development. Besides, trade openness, labour supply, and general government consumption significantly affect economic growth in SSA.

Conclusion: SSA countries should control corruption as well as open their economies so as to reap the positive effects of economy of scale derived from diversification.
\end{abstract}

Keywords: Institutional quality, Good governance, Social infrastructure, Corruption, Trade openness

\section{Introduction}

Researchers have sought to identify the factors that spur economies to grow, using the framework provided by endogenous growth theory following Romer (1986); Makiw, Romer and Weil (1992). This search for the determinants of economic growth has extended to the quest for why the African region has remained the poorest region in the world (Sala-iMartin 1997a; Levine and Renelt 1992; Bloom and Sachs 1998; Barro 199I, 1997). It has even been asked whether "something else", rather than the fundamental Solow variables, determine Africa's poor economic growth (Kilishi, Mobalaji, Yaru and Yakubu 20I 3; Easterly and Levine (200 I).

Five separate theses have emerged to explain growth/development differences across regions and countries, namely geography (Landes 1999; Diamond 1997; Sachs 2005), culture (Agbakoba 2003, 20II; Harrison and Huntington 2000; Diamond 2005; Ajah 2014), historical background (Rodney 1972; lkuenobe 1998; Oguejiofor 200I), trade (Stiglitz 2002, 2005),। and institution and policy factors (Meredith 2006; Meyns and Musamba 2010; Ezekwesili 2013). The first holds that countries in Africa experience low economic growth either because they are largely landlocked, or they are disadvantaged deterministically by climatic conditions. The second thesis holds that culture and cultural values determine development-enhancing or -impeding practices, and therefore societal progress. Thus, the predominance of values that do not promote efficiency and effectiveness is a factor that negatively affects economic growth in Africa. Arguments around historical antecedents hold that experiences of slavery, colonialism, and even neo-colonialism, had put Africa in a disadvantaged position by default. Trade literature argues that Africa is poorer because it has embraced liberal global trading and integration and is not able to cope with the politics of such a trade. Finally, the fifth thesis contends that weak institutions and wrong policy choices retard Africa's growth. 
The general lesson derived is that institution and good governance are two factors reshape the localized system that structure and determine economic performance (North 1990; Mauro 1995; Knack and Keefer 1995; Acemoglu, Johnson and Robinson 200I, 2004; Rodrik, Subramanain and Trebbi 2004; Huang 20I0). Sub-Saharan African (SSA) economies have been identified for their weak institutions, which may be responsible for their low growth trajectory over time. While this may be true, it is necessary to explore the concept of institution. The concept of institution looks like an envelope which contains something(s).

Kaufman, Kraay and Zoido-Lobatón (1999) defined governance as constituting the traditions and institutions by which power and authority in a country are exercised. According to them, governance deals with how governments are selected, monitored, and replaced; the capacity of government to formulate and implement sound policies; and the structures for the respect of citizens. The six specific components and possible criteria for measurement of governance are: (a) voice and accountability; (b) political stability and lack of violence; (c) government effectiveness; (d) regulatory quality; (e) rule of law; and (f) control of corruption. It has been easy to build on the liberal economists' arguments that capabilities of governance as defined by the market-enhancing governance model have been responsible for Africa's growth misfortunes. To buttress this argument, Commission for Africa (2005) clearly showed that the analysis of the lack of democratic accountability, the presence of patronclientele politics, extensive corruption (rent-seeking behaviours), and weak rule of law, are some of the reasons for Africa's relatively poor performance. This statement has found many supporters and followers within and outside of Africa.

Some authors have waded into why Africa has remained very poor. The World Bank (2016) showed that though the proportion of population living below $\$ 1.90$ a day in SSA declined from $54.3 \%$ in 1990 to $41.0 \%$ in 2013 , the number of people living below the international poverty line increased significantly from 276.I million in 1990 to 388.7 million in 2013 (Anyanwu, 2017). Also, Anyanwu (2017) stated that in 2013, the extreme poor in Sub-Saharan Africa represented more than half of the world's extreme poor of 766.6 million people. This shows that the region needs articulate policies and good institutions for her to development. Mberu and Eze (2017) asserted that divergent population factors help in achieving development goals while rapid population growth mars development in SSA. Looking at the links among demographic dynamics, governance and democratic development in Nigeria, Egharevba
(2017) complained that there has been no progress in development of Nigeria due to corruption, weak governance institutions, bad governance, decayed social and infrastructure services and non-integration of demographic issues into development plans. With the prevalence of rapid population growth, it has been asserted that Africa has remained a continent of impoverished nations trapped in poverty because according to Kremer (2003), these nations do not have sufficiently large educational investments or access to credit (Sachs 2005). In support of this, Oluwadamilola, Akinyemi, and Adediran (2018) also observed an insignificant investment in education. The governments of African countries have been blamed for various political poverty traps due to their inability and/or unwillingness to reform or adopt good economic policies. Several reasons have been adduced for the lack of reforms. Some of them are: incumbents' selfish interest to remain in power long enough to benefit from infrastructural reforms (Besley and Persson 20I I); incumbents' resistance to liberal policy reforms (North 1981; Acemoglu and Robinson 2006b; Cox, North and Weingast 2015).

However, Sachs, McArthur, Schmidt-Traub, Kruk, Bahadur, Faye and McCord (2004) argued that the specific Africa's characteristics such as low population density, vast and unoccupied areas, poor infrastructure, and the prevalence of difficult diseases make many of the conventional governance arguments irrelevant. They suggest that what Africa requires is "a big push" in infrastructural development and disease control before the continent can attain the level where governance can yield positive results in growth and development. In their study, they found different growth levels for various countries in sub-Saharan Africa (SSA), portraying the suggested variables rather than governance indicators.

However, Kaufmann et al. (2005) presented a point which undermines the argument made by Sachs. They submitted that while the general argument for a big push in Africa is not doubted and can be pursued as economic policy by countries in SSA, Sachs et al (2004) downplayed the importance of institutional capacity or governance capabilities which would help to implement the big push. Granted that SSA countries actually need the big push, it is germane to understand that even if the big push investment is available, the absence of good governance would also undermine the positive results anticipated from the push. If SSA countries have imbibed good governance models, even a little investment less than the 'big push' would yield results unimaginable to any observer. This underscores the foundational requirement of good governance in the growth process. 
Most studies on institutional quality as determinants of economic growth in SSA have focused mainly on political stability. However, this study sought to determine the impact of social infrastructure on economic growth of Sub-Saharan countries.

\section{Literature review and theoretical framework}

Growth theories generally support the view that physical capital, human capital and technological progress are the determinants of per capita output growth of a country. However, Acemoglu and Robinson (2010) argued that even though physical capital, human capital and technological progress are conventionally the proximate measures of differences in growth across countries, other fundamental factors which may cause differences in the proximate measures across countries are also essential in explaining cross-country differences in per capita growth. For instance, institutions create conducive environments such as patent right that promotes research and development (R\&D) and thus serves as an engine for knowledge creation (human capital). Hence, the role of institutions in an economy has been recognized as a fundamental factor in explaining the differences in economic growth across countries. Hall and Jones (1999) argue that productivity differences and long-lasting economic performance of countries are determined by social infrastructure and institutions which provide good economic environment in which economic agents accumulate physical and human capital to produce output. Related to this view, Tebaldi and Elmslie (2008) argued that good institution facilitates human capital growth through the establishment of a patent right that provides security and right incentives for those engaged in research and development. These arguments are in tandem with the views of new institutional theorists (North 1981, 1990, 1997; Rodrik, Subramanian, and Trebbi 2004; Greif 2006; Acemoglu and Robinson 2012; Acemoglu, Johnson, and Robinson 2002), who argue that institutions are the major cause of economic development and thus answer the question of why there are differences in growth across countries. The institutional theories explaining this conclusion is summarized by La Porta et al. (1999).

In La Porta et al (1999), theories of institutional development identify as well as explain factors that can influence the formation and persistence of a given quality of institutions in the society for sustained economic and political development. Theories of institutional development are classified into three categories: economic, political and cultural institutional theories. According to Demsetz (1967) and North (198I), economic theories of institutional development assert that institutions are established when it is efficient to create them. This entails that institutions are built when the anticipated social benefits considerably exceed the anticipated attendant costs. Political theories of institutional development, developed by North (1990) and Olson (1993), focused on the redistribution of societal resources by political leaders in a way to extract economic rents to themselves. This is evident in most of the African countries, from the time of colonial rule to present, where political conflicts between different groups regarding the sharing of national values and policy preferences occur frequently and as a result, policies are based on political favouritism rather than efficiency (Adewole \& Osabuohien, 2007). In Douglas North's (1990: I I0) view, "Third World countries are poor because the institutional constraints define a set of payoffs to political/economic activities that do not encourage productive activity". For instance, Onwuka (2006) noted that most political leaders in Africa are not proactive in investing in productive sectors like human capital which are vital routes of escape from poverty in the face of rapid population growth. Similarly, Acemoglu and Robinson (2012) contended that economic policy, value system, culture, or geography do not guarantee success or failure of any nation rather success or failure of nations depends on their institutions. They argued that political institutions define nations' economic institutions, which ultimately determine their success or failure. They categorized political institutions into extractive and inclusive institutions. An extractive institution refers to a situation where few groups of individuals control the resources and exploit the rest of the society, whereas inclusive institution refers to a situation where many people are involved in political affairs limiting several forms of exploitation of the masses. They buttressed that essential services such as contract enforcement, justice, and education which boost economic agents' confidence and also encourage innovation are usually provided in a regime of inclusive institutions. On the other hand, extractive institution provides a hostile environment that breeds inequality, injustice, and uncertainty which are inimical to innovation and growth. With respect to Africa, Acemoglu and Robinson (2010) contend that the continent is trapped in a set of economic and political institutions that are not conducive to economic progress. Africa's paradigm shift from colonialism did not generate a transition from the extractive to an inclusive institutional sphere. Instead, post-colonial African countries basically retained extractive institutions in African outfit (Acemoglu and Robinson 2010). Similarly, Acemoglu et al $(2003,2005)$ opine that the institution 
introduced by the colonial masters were fundamental to both past and present economic growth in Africa.

Finally, cultural theory of institutional development (Putnam 1993; Landes 1998) assert that a given society holds beliefs and norms that are deeply entrenched and rooted in culture, religion, history, or language which shape the collective actions of such society. In this regard, some societies have cultures that support institutions that encourage trade, investment and markets; while some others have cultures that are hostile to markets, preventing them from creating institutions that boost trade and investment. For instance, Landes (1998) argued that Protestantism promoted industrialization in Northern Europe, because its ideological principle became an integral part of the ideology of capitalism by generalizing the virtues of hard work, diligence, and thrift as earthly signs that individuals are maximizing the talents given to them by God for His overall purpose. In the protestant viewpoint, salvation is associated with achievements on this earth. It has been argued that the quality of governments at local levels in contemporary Italy can be traced back to the early period of development of social capital: the network of associations that promote trust and help resolve collective action problems (Putnam 1993).

Based on the aforementioned theories, several empirical studies relating to institutional economics have underscored the significance of institutions for economic growth and development. The success of economies in achieving high levels of economic growth requires appropriate legal and economic frameworks, as well as reform of the rules and institutions that govern the strategic interaction of the participants in the political game (Ngendakuriyo 2009). In a cross-sectional, time-series data with static panel using fixed effects and dynamic panel using system GMM, Nawaz (2015) finds in an analysis of 56 developed and developing countries between 1981 and 2010 that the effect of institutional quality on economic growth depends on the stage of development and that it performs more role in determining growth in high-income countries relative to low-income countries. For instance, he found that control over corruption, qualitative and effective bureaucracy, and desirable law and order have greater positive impacts on economic growth in highincome economies than developing economies. The impact of robust investment profile is more growthenhancing in developing economies in contrast to developed ones. Valeriani and Peluso (20II) used pooled regression and fixed effects for the panel of $18 \mid$ countries, analyzed the impact of quality of institutions on economic growth at different stages of development. The result revealed a positive impact of institutions on growth when measured with civil liberties, quality of government, and number of veto players. They also confirmed that institutions are more efficient in developed countries than in developing countries. Góes' (2016) analysis of 119 countries for over 10 -year period revealed a positive impact of institutional quality on economic growth.

While there is an apparent consensus in the literature that quality of institutions matter for economic growth, the literature focus has been shifted to channels through which institutional quality affect growth. Numerous empirical studies since the work of North (198I) have been carried out to identify the channels through which quality of institutions relate to economic growth. The empirical findings in this regard are widely divided on the nature and channels of the relationships between institutional quality and economic growth. Some studies support the idea that economic institutions are more relevant to growth (Weil 2008; Acemoglu and Robinson 2008; Valeriani and Peluso 20I I), while others have come to the conclusion that political institutions are more growth-enhancing (Green 2009; Hicken; Satyanath and Sergenti 2005). Yet, some other studies have argued that democratic regime is more relevant to growth than authoritarian regime.

The institutional theorists that identify economic institution to be the most significant are of the view that growth driven by R\&D distilled from endogenous growth depends on the presence of high quality economic institutions such as freedom of movement across occupations and/or sectors, free markets, and property rights, especially intellectual property rights. Acemoglu and Johnson (2005) have empirically tried to validate the effects of economic institutions on growth by comparing "contracting" and "property rights" institutions. Constraints on the executive were used in the analysis to the proxy contracting institution while property rights were measured by legal variables. The result revealed that legal variables are more significant for growth. Papaioannon (2009) opined that improved institutions increase capital flows between countries in contrast to institutions' fragility indices such as legal inefficiency, inefficient protection of property rights and high risk of expropriation. Rodrik, Subramanian and Trebbi (2004) in their study showed the positive and significant impacts of institutional environment on long-term economic growth by examining the rule of law and property rights. Similarly, Knack and Keeler (1995) revealed that institutions exert significant impacts on investment and economic growth using property rights and contracts as proxy for institutional quality. Acemoglu, Johnson and Robinson (200I) focused on property rights as an approach to assess institutional quality. They acknowledged that the significance of the institutional framework is so 
fundamental that "once the effect of institutions is controlled for, countries in Africa or those closer to the equator do not have lower incomes".

Another study used as a standard reference on the empirical relationship between institutional conditions and economic growth was carried out by North (1990). The study revealed direct and indirect effects of institutional framework on economic growth. He argued that government with improved institutions creates conducive environment (such as lowering the risk and cost of transactions) and confidence required for an economic agent to thrive. This implies that bureaucratic obstacles, bribery, and rent-seeking result in high transaction costs and ultimately distrust, disincentive for investment, and retarded growth. In an environment of uncertainty and distrust with regard to property rights enforcement, business operation of firms will be based on the short-term horizon for the fear of unknown. Thus, countries that secure property rights tend to develop faster (North 1990). An economy with fragile institutions is more inefficient as more inputs are needed for the production of the same output (Sala-i-Martin 2002). Meisel and Ould-Aoudia (2008) introduced the concept of governance for development, which covers the various institutional arrangements that produce the confidence needed for development. Dias and Tebaldi (2012) examined the link between human capital development, institutions, and economic growth using crosscountry panel data for the period 1965 to 2005 . Their finding revealed that the structure of an institution in a state is shaped by historical antecedent of an economy with the attendant effect on longterm economic performance. The result also showed no relationship among the political institution and productivity and long-term economic growth.

With respect to political institution, some institutionalists argued that the impact of political constraints is not direct but rather sets the environment in which economic institutions thrive. Recent studies have reaffirmed this position. Flachaire, García-Peñalosa and Konte (2014) found from an analysis of 79 countries both developed and developing, for the period 1975 to 2005 that political institutions are the major causes of growth, because they set/determine the environment in which economic institutions operate. They established that political institutions set regime for an economy to operate, whereas economic institutions produce direct impacts on rates of growth within each regime. Larsson and Parente (20II) examined the way in which autocratic and democratic regimes choose policies and observe their impact(s) on economic growth. They observed that different autocratic regimes select different policies based on their preferences irrespective of the choice of the masses. Some autocrats impose policies that benefit few individuals/groups even if it is at the expense of others or detrimental to growth, while some autocrats adopt policies that are favourable to growth even when this produce costs for some sectors/sections of the electorate. Another argument in favour of the idea that political institutions are more growth-enhancing was put forward by Acemoglu (2008), who contended that democracies may have a better opportunity to benefit from technological progress. He argued that at the early development stage, autocracies may produce faster growth if they implement an appropriate yet expensive policy.

From the literature search, there has been a consensus that quality of institutions affects economic growth, but we observed dearth of empirical evidence on the studies of the impact of social infrastructure on economic growth in sub-Saharan African countries. Scanty empirical evidence exists in literature on the influence of institutions on economic growth; this necessitates the need for this study.

\section{Data sources and methods}

The theoretical framework of this study is derived from the neo-classical Solow (1956) growth model. This model states that accumulation of physical capital and technical progress are the drivers of economic growth. The basic assumptions behind the Solow model are: constant returns to scale, diminishing marginal productivity of capital, exogenously determined technical progress and substitutability between capital and labour (Petrakos, et. al., 2007). The neo-classical model is modified to include several other variables such as institutional factors, labour supply, property rights protection and market system (Barro, 1996). It is also argued that the growth of an economy is also driven by institutional factors which can block diminishing returns of capital, enhance capital's marginal product, hence improves output growth. This motivates our study's focus on social infrastructure especially as it concerns sub-Saharan Africa (SSA) countries. However, the Solow model was modified by the new (endogenous) growth theory which introduced other variables such as government expenditure and source of governance indicators. It is on the basis of the new growth model (or endogenous growth model) that we built the model of this study.

Therefore, to determine the influence of social infrastructure on economic growth in sub-Saharan African countries, we formulated, in line with Barro (1990) an economic growth model with the following:

$$
y_{i t}=\alpha+\beta^{\prime} X_{i t}+\epsilon_{i t} \ldots \ldots \ldots \ldots \ldots \ldots \ldots \ldots . . . .3 .1
$$

http://aps.journals.ac.za 
The error term $\epsilon_{i t}$ is equal to $\eta_{i}+\epsilon_{i t}$, where $\eta_{i}$ are individual fixed effects and $\epsilon_{i t}$ are the idiosyncratic shocks. $y$ is gross domestic product per capita; $X$ is the vector of growth determinants which include general government final consumption expenditure, trade openness, gross fixed capital formation, labour supply and foreign direct investment Barro (1996); Nwodo and Asogwa (2017); Kodongo and Ojah (2016).

We augment equation (3.I) with a social infrastructure variable, $Z$, as follows:

$$
y_{i t}=\alpha+\beta^{\prime} X_{i t}+\lambda Z_{i t}+\epsilon_{i t} \ldots \ldots \ldots \ldots \ldots \ldots \ldots . . .3 .2
$$

Data for this study were time series data on institutional variables and gross domestic product (GDP). Data on institutional variables (specifically on quality of governance (Q०G)) were collected from the World Governance Indicators, while data on gross domestic product (GDP) per capita of the subSaharan African countries involved as well as other control variables were sourced from World Development Indicators (WDI), all published by The World Bank (2017). The qualities of the data, for all intent and purposes, are high and reliable; the data are valid for this study and data source properly archived. Data spanned from 2002 to 2016 , because some countries studied had missing data. Data on a total of 47 SSA countries were used, namely, Angola, Benin, Botswana, Burkina Faso, Burundi, Cameroon, Cape Verde, Central African Republic, Chad, Comoros, Congo (Brazzaville), Congo (Democratic Republic), Côte d'Ivoire, Djibouti, Equatorial Guinea, Eritrea, Ethiopia, Gabon, The Gambia, Ghana, Guinea, Guinea-Bissau, Kenya, Lesotho, Liberia, Madagascar, Malawi, Mali, Mauritania, Mauritius, Mozambique, Namibia, Niger, Nigeria, Rwanda, Sao Tome and Principe, Senegal, Sierra Leone, Somalia, South Africa, Sudan, Swaziland, Tanzania, Togo, Uganda, Zambia, and Zimbabwe. Three countries, namely, Réunion, Seychelles and Western Sahara, were not included in the study because of the paucity of data on them.

The variable, $Z$, from equation 3.2, includes social infrastructure indices (Voice and Accountability (VAA), Political Stability and Absence of Violence/Terrorism (PSAT), Government Effectiveness (GE), Regulatory Quality (RQ), Rule of Law (RoL), and control of Corruption (CC)) obtained from the World Governance Indicators (WGI). These institutional variables represent social infrastructure as defined by Kaufman et al, (1999) and documented by World Bank's World Governance Indicators (WGI). WGI is a database of the World Bank Group on the quality of governance as supplied by enterprises, citizens and experts in developed and developing economies. The WGI contains six indicators namely, Voice and Accountability, Political Stability and Absence of Violence/Terrorism, Government Effectiveness, Regulatory Quality, Rule of Law and Control of Corruption. In this study, only three indicators related to social infrastructure were considered namely, voice and accountability (VAA), regulatory quality (RQ) and control of corruption (CC).

Equation 3.2 above may not pose many challenges in estimating the degree of impact of the independent variable on the dependent variable. This means that the standard panel data estimation - fixed effect (FE) and random effect (RE) are unbiased. However, before the decision on which of fixed effect or random effect to adopt, a Hausman test was carried out and the result favoured fixed effect estimation. And, to check for the problem of unequal variance of the error term which is a likely problem with fixed effect estimation, the study did a robust assessment of standard error of the estimate.

Another possible problem that could hamper the results from this model is a possible cross-sectional dependence of the error terms which have to do with the assumption of unobservable time-varying omitted common variables that affect each country. If these unobservable common variables are not correlated with the explanatory variables, then the coefficient estimates based on the OLS or FE regression are consistent while the estimated standard error are biased. However, as Baltagi (2008) has shown that cross-sectional dependence is only a problem in macro panels with long time series of over 20 years and since the scope of our study covers a period of 15 years, the FE effect estimator is more suited for the study. The econometric software used is Stata I3 (Stata 2013) package which is best suited for panel data analysis.

\section{Results}

As stated earlier, the determination of which panel estimation technique to use (out of fixed effect and random effect) was dependent on the outcome of Hausman test. The results of the Hausman's test are therefore presented in Table I below: 
Table I: Summary results of the Hausman model selection test

\begin{tabular}{llccc}
\hline Variables & $\begin{array}{l}\text { Coefficient } \\
\text { (b) }\end{array}$ & $\begin{array}{l}\text { (B) } \\
\text { fixed }\end{array}$ & $\begin{array}{l}\text { Difference sqrt (diagv_b_v_B)) } \\
\text { random }\end{array}$ & $\begin{array}{l}\text { (b-B) } \\
\text { S.E }\end{array}$ \\
\hline Voice \& Accountability & -0.0000000319 & 0.00000000215 & -0.00000000247 & - \\
Control of Corruption & 0.00000000527 & 0.00000000505 & 0.0000000219 & - \\
Regulatory Quality & -0.000000047 & 0.00000000146 & 0.00000000194 & - \\
Gen. Govt. Final Cons. Exp. & 0.787753 & 1.246929 & -0.4591761 & - \\
Trade Openness & -2751.014 & -3236.533 & 485.5188 & - \\
Gross Fixed Cap. Formation & 1.320874 & 1.369498 & -0.0486237 & 0.348166 \\
Labour Supply & 5646.416 & 4399.043 & 1247.373 & 364.2758 \\
Foreign Direct Investment & 0.3040418 & 0.2669896 & 0.370522 & -
\end{tabular}

$\mathrm{Chi}^{2}(3)=(\mathrm{b}-\mathrm{B})\left[\left(\mathrm{V}_{-} \mathrm{b}-\mathrm{V}_{-} \mathrm{B}\right)^{\wedge}{ }^{\wedge}(-\mathrm{I})\right](\mathrm{b}-\mathrm{B})=24.05$ Prob $>\mathrm{chi}^{2}=0.0000$ (v_b_v_B is not positive definite)

Table I shows that fixed effect was the accepted technique. We therefore rejected the null hypothesis that difference in coefficients is not systematic and adopt a fixed effect estimation technique for the study. The estimated $x^{2}$ is 24.05 and the probability value is 0.0000 . This signifies that the result is statistically significant; that the rejection of null hypothesis is appropriate on the use of random effect method of panel data econometrics, and that the fixed effect method accepted.

We estimated the model in equation (3.2) using a panel of all 47 sub-Saharan African countries in our sample. We adopted the Panel Fixed Effect (FE) model.

Table 2: Summary results of the fixed effect (panel) model

\begin{tabular}{|c|c|c|}
\hline Variable & Fixed Effect (fe) & Random Effect (re) \\
\hline Voice \&Accountability & -0.00000003194 & 0.000000002147 \\
\hline Control of Corruption & $0.000000005268^{*}$ & 0.000000005049 \\
\hline RegulatoryQuality & -0.00000004773 & $0.00000000 \mid 460$ \\
\hline Govt. Gen. Final Cons. & $0.7877530 I^{* * * *}$ & |. $246929 \mid * * *$ \\
\hline Trade Openness & $-2751.0142 * * *$ & $-3236.533 * * *$ \\
\hline Gross Fixed Cap. Formation & I.3208743**** & I.369498*** \\
\hline Labour Supply & $5646.4165^{* * * *}$ & $4399.043 I^{* * * * *}$ \\
\hline Foreign Direct Investment & $0.30404 \mid 79$ & 0.26698962 \\
\hline -Constant & $-1.359 e+10 * * *$ & $-5.294 e+09$ \\
\hline $\mathrm{N}$ & 474 & 474 \\
\hline $\mathrm{R}^{2}$ & 0.85800346 & \\
\hline $\mathrm{R}^{2}$ Adj & 0.8419662 & \\
\hline
\end{tabular}

\section{Discussion}

Following from the results in Table 2, two measures of social infrastructure are statistically insignificant to economic growth, namely, voice and accountability 4946
(VAA) and regulatory quality (RQ). This could be due to the poor level of social infrastructure in subSaharan Africa. However, the fixed effect model shows that control of corruption significantly affected http://aps.journals.ac.za 
economic growth in sub-Saharan Africa. Both voice and accountability and regulatory quality have negative relationship with economic growth. This means that while suppressing voice and accountability undermines compliance from citizens limits their freedom to participate in private enterprise, economic growth can be reduced (Buehn and Schneider (2009: 15); and regulatory restraints and bureaucratic bottlenecks hamper economic growth (Choi and Thum 2005). The variables did not have significant influence economic growth. This might be due to lack of trust and confidence in the leadership. Thus, citizens feel cheated and go about their business without waiting for government. This outcome suggests that the level of voice and accountability, and regulatory quality for the period under study did not affect economic growth in SSA countries. This finding is in line with that of Kodongo and Ojah (2016). It suggests that the level of social infrastructure and the channels in which the social infrastructure transmits to economic growth need further review. On the other hand, the finding that control of corruption is significantly affecting economic growth of SSA countries signifies that when corruption is controlled, development plans in diverse sectors can be implemented. The coefficient on the control of corruption is supported by the findings of Rodrick (2002) and Lee \& Kim (2009) that the fight against corruption is important for motivating/spurring economic growth.

Exploring the impact of control variables on economic growth in SSA economies, especially for policy and confirmation purposes, it can be observed from the results that among antecedents of growth, labour supply which is a proxy of human capital is statistically significant for economic growth of SAA economies. This is in line with the findings of Easterly and Levine (200I) and Pritchett (2004). Other major growth determinants in literature applied in the model which include government consumption, trade openness and gross fixed capital formation are significant to economic growth in the economies of sub-Saharan Africa. From this analysis, when nations open up for trade, it would lead to technology spillover and improvement in productivity. There is no doubt that SSA countries would benefit from a technological transfer that can speed up growth and sustainable development.

\section{Conclusion}

The paper studied the impact of the quality of social/institutional infrastructure on economic growth of sub-Saharan Africa (SSA) countries, using fixed effect panel data econometric analysis. Three social infrastructure variables (voice and accountability (VAA), control of corruption (CC) and regulatory quality (RQ) were used in the analysis, in addition to other control variables such as trade openness, general government consumption expenditure, private investment (proxy of gross fixed capital formation), labour supply and foreign direct investment (FDI).

From the analysis, it was found out that of all social infrastructure variables considered, control of corruption (CC) showed statistically significant influence on the growth rate of economies in SSA, while voice and accountability and regulatory quality do not have statistical influence. However, all the control variables, except foreign direct investment (FDI), showed statistical significance on economic growth on countries in Sub-Saharan Africa. The reason could be that SSA economies have been threatened by the activities of the terrorist groups operating in several parts of the region which scared foreign investors away. Terrorists have been ravaging Nigeria (the largest destination of FDI), Niger, Mali (the Sahel region), Somalia, some parts of Kenya, and so on. It is possible that foreign investment (which may have declined) does not improve the growth of SSA (Ukwueze, Asogwa, Nwodo and Ogbonna 2019).

One of the implications of the findings of this study is that sub-Saharan African countries should always pursue a policy of nipping in the bud cankerworms such as corruption, terrorist activities, and so on, which set the sub-region backwards. This means that nations in the sub-region should control corruption so that the little resources they have would be judiciously utilized to enhance economic growth and sustainable development. Development of the region will take place if the scarce resources are efficiently used.

Another implication of the findings of this study is that governments of sub-Saharan African countries should create conducive environment for private domestic investment to thrive as this will ensure increase in private investment and economic growth. Thus, these countries should design policies that will make their economies to be more open to trade since trade is an engine of economic growth (Frankel and Romer 1999). Implementing these and related recommendations will ensure that SSA countries contribute their quota in the realization of the broad goals of the African Continental Free Trade Area (AfCFTA) as well as the AU Agenda 2063 of inclusive growth and sustainable development of Africa in the next 50 years.

\section{References}

Acemoglu, D.; Johnson, S. and Robinson, J. A. 200I. The colonial origins of comparative development: 
An empirical investigation, American Economic Review, 9I(5), |369-|40|.

Acemoglu, D.; Johnson, S., \& Robinson, J. A. 2002. Reversal of fortune: geography and institutions in the making of the modern world income distribution, The Quarterly Journal of Economics, I I 7(4), | 23I-I 294.

Acemoglu, D.; Johnson, S.; Robinson, J. and Yared, T. 2003. Institutional causes, macroeconomic symptoms: Volatility, crises and growth, Journal of Monetary Economics, 50(I), 49-I 23.

Acemoglu, D., Johnson, S. and J. Robinson, 2004. Institutions as the fundamental cause of long-run growth, Prepared for the Handbook of Economic Growth

Acemoglu, D., \& Johnson, S. 2005. Unbundling institutions, Journal of Political Economy, I/3(5), 949-995.

Acemoglu, D., Johnson, S., and Robinson, J. A. 2005. Institutions as a fundamental cause of long-run growth, Handbook of Economic Growth, IA, 385-472, DOI: IO.I016/SI574-W84(05)OloW

Acemoglu, D., Cutler, D., Finkelstein, A., and Linn, J. 2006. Did Medicare induce pharmaceutical innovation? American Economic Review, 96(2), 103-107.

Acemoglu. D. and Robinson, J. A. 2006b. Economic backwardness in political perspective, American Political Science Review. I00(I): I I5- I 3 |

Acemoglu, D. and Robinson, J. 2008. The role of institutions in growth and development, TheWorld Bank, Washington DC.

Acemoglu, D.; Johnson, S.; Robinson, J. A. and Yared, P. 2008. Income and democracy, American Economic Review, 98(3), 808-42.

Acemoglu, D. and Robinson, J. 2010. The role of institutions in growth and development, Review of Economics and Institutions, I (2), I - 30.

Acemoglu, D.; Johnson, S., and Robinson, J. A. 2012. The colonial origins of comparative development: An empirical investigation; Reply, American Economic Review, 102(6), 3077-3I I 0.

Adewole, M. A., \&Osabuohien, E. S. 2007. Analysis of the cost of government and options for its redistribution in Nigeria, The Nigeria Journal of Economic and Social Studies, 49(I), I 37 - I59.

Agbakoba, J. C. A. 2003. Philosophical issues in development. Enugu: Fourth Dimension Publishers.

Agbakoba, J. C. A. 20II. Choice, Responsibility and Traditional African Values in the Development of Africa, A paper presented at the Symposium Afrika in Aubruch: Analysen und Impulse in Interdisziplinarer und InterkulturellerPrespective, Wilhelm KempfHaus in Wiesbaden-Naurod,
(University of Frankfurt, Germany, 25 November, 20I I)

Ajah, A.C. 2014. On truthful narrative-identity and a development model for Nigeria. Open Journal of Philosophy, 4(4), 53I-540. http://dx.doi.org/10.4236/ojpp.2014.44055

Anyanwu, J. C. 2017. The key drivers of poverty in sub-Saharan Africa and what can be done about it to achieve the poverty sustainable development goal, Asian Journal of Economic Modelling, 5(3), pp. 297-317, 10.18488/journal.8.2017.53.297.317.

Baltagi, B. 2008. Econometric Analysis of Panel Data, West Sussex, UK: John Wiley \& Sons Ltd.

Barro, R. J. 1990. Government spending in a simple model of endogenous growth, Journal of Political Economy, 98(S5), SI 02 - SI 25.

Barro, R. J. I99I, Economic growth in a cross section of countries, The Quarterly Journal of Economics, 106(2), pp. 407-43.

Barro, R. J. 1996. Determinants of economic growth: A cross-country empirical study, National Bureau of Economic Research, Working Paper 5698.

Barro, R. J. 1997. Determinants of economic growth (MIT Press, Cambridge, MA).

Bates, R. H. and Bloc, S. 20I7. Political institutions and economic growth in Africa's 'Renaissance', Oxford Economic Papers, Oxford University Press, I-26, doi: 10. 1093/oep/gpx049

Besley, T. and Persson, T. 20I I. Pillars of Prosperity. Princeton: Princeton University Press.

Bloom D. and J. Sachs 1998. Geography, demography and economic growth in Africa, Brookings Papers on Economic Activity, (1998-2), pp207 -

295, DOI: 10.2307/2534695.

Buehn, A. and Schneider, F. 2009.Corruption and the shadow economy: A structural equation model approach, Institute for the Study of Labor. IZA DP No. 4182.

Choi, J. P. and Thum, M. 2005. Corruption and the shadow economy, International Economic

Review, 46: 817-836.

Commission for Africa 2005. Our Common Interest: Report of the Commission for Africa, London: Commission for Africa.

Cox, G. W., North, D C. and Weingast, B. 20I5. The violence trap: A political-economic approach to the problems of development, Working Paper, Hoover Institution, Stanford University.

Diamond, J. 2005. Collapse: How societies choose to fail or succeed. New York: Viking/Penguin Group.

Dias, J., \& Tebaldi, E. 20/2. Institutions, human capital, and growth: The institutional mechanism, Structural Change and Economic Dynamics, 23(3), 300-312. 
Demsetz, H. 1967. Toward a theory of property rights, American Economic Review, 2, Papers and Proceedings of the Seventy-ninth Annual Meeting of the American Economic Association, 57(2), 347-359.

Easterly, W. and Levine, R. 200I. What have we learned from a decade of empirical research on growth? It's not factor accumulation: stylized facts and growth models, The World Bank Economic Review 15, 177-219.

Egharevba, Matthew 2017. Demographic dynamics, governance and the attainment and democratic development: The case of Nigeria, African Population Studies, 3I(2), pp. 3769 - 3786, http://aps.journals.ac.za.

Ezekwesili, O. 2013. The wealth and poverty of a nation: Who shall restore the dignity of Nigeria? $42^{\text {nd }}$ Convocation Lecture, University of Nigeria, Nsukka. University of Nigeria Press, Nsukka.

Flachaire, E., García-Peñalosa, C., \&Konte, M. 2014. Political versus economic institutions in the growth process, Journal of Comparative Economics, 42(I), 21 2-229.

Frankel, J. A. and Romer, D. 1999. Does trade cause growth? The American Economic Review, 89(3), 379-399.

Góes, C. 2016. Institutions and growth: A GMM/IV panel VAR approach, Economics Letters, 138, 859I, Elsevier, DOI: 10.1016/j.econlet.2015.II.024.

Green, Alan Morgan 2009. The role of political institutions in economic development: an empirical investigation, A Doctoral Dissertation Presented to the Faculty of the Graduate School, Cornell University.

Greif, A. 2006. Institutions and the Path to the Modern Economy: Lessons from Medieval Trade, Cambridge University Press.

Hall, R. E. \& Jones, C. I. 1999. Why do some countries produce so much more output per worker than others? The quarterly journal of economics, I I $4(\mathrm{I})$, 83-I I6.

Harrison, L. and Huntington, S. (eds.). 2000. Culture matters: How values shape human progress. New York: Basic Books.

Hicken, Allen; Satyanath, Shanker and Sergenti, Ernest 2005. Political institutions and economic performance: The effects of accountability and obstacles to policy change,

American Journal of Political Science, 49(4), pp. 897907.

Huang Y. 20I0. Political institutions and financial development: An empirical study, World Development, World Development, 38(I2), pp. 1667-1677, Elsevier Ltd, doi:10.1016/j.worlddev.2010.04.001.
Ikuenobe, P. 1998. Colonialism in Africa, culturally induced moral ignorance, and the scope of responsibility, Journal for the Theory of Social Behaviour, 28(2), 109-128

lyoha, M. A. 1999. External debt and economic growth in Sub-Saharan African countries: An econometric Study, African Economic Research Consortium, AERC Research Paper 90.

Jared, D. 1997. Guns, germs, and steel: The fates of human societies. New York:W.W. Norton \& Company.

Kaufmann, Daniel, Kraay, Aart and Zoido-Lobatón, Pablo 1999. Governance Matters, Preliminary and Incomplete Comments Welcome, The World Bank.

Kaufmann, Daniel, AartKraay and Massimo Mastruzzi 2005. Governance matters IV: governance Indicators for 1996-2004, World Bank Policy Research Working Paper No. 3630. Available HTTP:

<http://www.worldbank.org/wbi/governance/pub s/govmatters4.html>

Khan, M. H. 2008. Governance and development: The perspective of growth-enhancing governance, in GRIPS development forum (ed.) diversity and complementarity in development aid: East Asian lessons for African growth, Tokyo: National Graduate Institute for Policy Studies 2008. pp. 107-52

Kilishi, A. A.; Mobalaji, H. I.; Yaru, M. A. and Yakubu, A. T. 20/3. Institutions and economic performance in Sub-Saharan Africa: A dynamic panel data analysis, Journal of African Development, Fall, I5(2), pp. 9I - 120.

Knack, S., \& Keefer, P. 1995. Institutions and economic performance: cross-country tests using alternative institutional measures, Economics \& Politics, 7(3), 207-227.

Kremer, M. 2003. Randomized evaluations of educational programs in developing countries: some lessons, The American Economic Review, 93(2), pp. 102-106.

La Porta, R., Lopez-de-Silanes, F., Shleifer, A., \&Vishny, R. 1999. The quality of government, The Journal of Law, Economics, and Organization, 15(I), 222-279.

Landes, D. S. 1999. The wealth and poverty of nations. New York: W.W. Norton.

Larsson, A., \&Parente, S. L. 20II. Democracy as a Middle Ground: A Unified Theory of Development and Political Regimes!mimeo.

Lee, K. and Kim, B. Y. 2009. Both institution and policies matter but differently for different income groups of countries: Determinants of Long Run Economic Growth Revisited,World Development, 37, 533-549. 
Levine, R. and Renelt, D. 1992. A sensitivity analysis of cross-country growth

regressions, American Economic Review, 82(4), PP 942-963.

Makiw, N. G; Romer, D. and Weil, D. N. 1992. A contribution to the empirics of economic growth, Quarterly Journal of Economics, I07(2), pp. 407 437.

Mauro P. 1995, Corruption and growth, Quarterly Journal of Economics, II0(3), pp 68I-7I 2.

Mberu,Blessing Uchenna and Ezeh, Alex Chika 2017. The population factor and economic growth and development in Sub-Saharan African countries, African Population Studies, 3I(2), pp. 3833 3844, http://aps.journals.ac.za

Meisel, N. \&Aoudia, J. O. 2008. Is 'Good Governance' a good development Strategy? Working Paper 58, AgenceFrancaise de development, Paris. AFD.

Meredith, M. 2006. The state of Africa: A history of fifty years of independence. New York: Free Press.

Meyns, P. and Musamba, C. (eds.). 2010. The developmental state in Africa: Problems and prospects. Institute for Development and Peace: Duisburg-Essen.

Nawaz, S. 2015. Growth effects of institutions: A disaggregated analysis, Economic Modelling, 45, I/8-I26,

doi.org/10.1016/i.econmod.2014.11.017.

Ngendakuriyo, F. 2009. Institutions quality and growth, Georgia Institute of Technology, Discussion Paper 2009 - 14.

North, D. C., \& Thomas, R. P. 1973. The rise of the western world: A new economic history. Cambridge University Press.

North, Douglass C. 198I. Structure and change in economic history. New York: W.W. Norton.

North, D.C. 1990. Institutions, institutional change, and economic performance, New York, Cambridge University Press.

North, D.C 2005. Understanding the process of economic change. New Jersey. Princeton University Press

Nwodo, O.S. and Asogwa, F. O. 2017. Global integration, Non-oil export and economic growth in Nigeria, .Academic Journal of Economic Studies. 3(I): 59-67.

Odongo K. and Kalu O. 2016. Does infrastructure really explain economic growth in Sub-Saharan Africa? Economic Research Southern Africa (ERSA), Working Paper 653

Oguejiofor, J. 200I. Philosophy and the African predicament. Ibadan: Hope Publications.

Oluwadamilola, O., Akinyemi, O., \& Adediran, $O$. (2018). Human capital development and inclusive growth: Implications for achieving SDG-4 in Nigeria. African Population Studies, 32(I), 40884096.

Olson, M. 1993. Dictatorship, democracy, and development, American Political Science Review, 87(3), 567-576.

Onwuka, E. C. (2006). Another Look at the Impact of Nigeria's Growing population on the

Country's Development. African Population Studies, 2I(I).

Papaioannou, E. 2009. What drives international financial flows? politics, institutions and other determinants, Journal of Development Economics, 88(2), 269-28I.

Petrakos, George; Arvanitidis, Paschalis and Pavleas, Sotiris 2007. Determinants of economic growth: The experts' view, dynamic regions in a knowledge- driven global economy (DYNREG), Lessons and Policy Implications for the EU, Working Paper, 20.

Pritchett $L$ and Woolcock M. 2004. solutions when the solution is the problem: arraying the disarray in development, World Development, 32(2), pp. 19/-2/2, doi:10.1016/j.worlddev.2003.08.009.

Putnam, R. D., Leonardi, R., and Nanetti, R. Y. 1994. Making democracy work: civic traditions in modern Italy, Princeton University Press.

Rodrik, D. 2002. Introduction, In: Rodrik, D. (ed.), In search of Prosperity: Analytic Narratives of Economic Growth, New Jersey: Princeton University Press, I - 19.

Rodrik, D., Subramanian, A., \&Trebbi, F. 2004. Institutions rule: The primacy of institutions over geography and integration in economic development, Journal of Economic Growth, 9(2), |3/-I65.

Romer, P. M. 1986. Increasing returns and long run growth, Journal of Political Economy, 94(5), pp. 1002 - 38.

Rodney, W. 1972. How Europe underdeveloped Africa. Lagos: Panaf Publishing, Inc.

Sachs, Jeffrey D., John W. McArthur, Guido SchmidtTraub, Margaret Kruk, Chandrika Bahadur, Michael Faye and Gordon McCord 2004. 'Ending Africa's Poverty Trap', Brookings Papers on Economic Activity 2004 ( I): I I 7-240.

Sachs, J. 2005. The end of poverty: How we can make it happen in our lifetime. New York: Penguin Books.

Sala-i-Martin X. 1997a. I Just Ran Two Million Regressions", American Economic

Review, 87(2), pp I78 - I83

Sala-i-Martin, X. 200I. I5 Years of New Growth Economics: What have We Learnt? Central Bank of Chile, Working Paper 172. 
Sikod, F. and Teke, J. N. 20/2. Governance and Economic Growth in Cameroon, African Economic Research Consortium, Nairobi, AERC Research Paper 250.

Stata I3 20I3. A Stata Press Publication, StataCorp LP, College Station, Texas: Stata Press.

Stiglitz, J. 2002. Globalization and its discontents. New York: W.W. Norton Company.

Stiglitz, J. and Charlton, A. 2005. Fair trade for all. New York: Oxford University Press.

Sundaram, J. K. and Chowdhury, A. 2013. Is Good Governance a Pre-requisite for Africa's Development?!nBahruZewde (eds), Africa Review of Books, The Council for the Development of Social Science Research in Africa (CODESRIA), 9(2), pp. 4- 7.

Tebaldi, E., \&Elmslie, B. 2008.Institutions, Innovation and Economic Growth,Journal of Economic Development, 33(2), 27.

Ukwueze, E. R., Asogwa, H. T., Nwodo, O. S., and Ogbonna, O. E. 2019. Impact of Terrorism on Foreign Direct Investment in Nigeria, In Ramesh C. Das (eds), The Impact of Global Terrorism on Economic and Political Development: Afro-Asian
Perspectives (pp. 235-247). Emerald Publishing Limited, Chapter 18.

Valeriani, E., \&Peluso, S. 20II. The Impact of Institutional Quality on Economic Growth and Development: An empirical study, Journal of Knowledge Management, Economics and Information Technology, I(6), I - 25.

Weil, D.N. 2008. Economic growth, London: Pearson.

The World Bank 198I. Accelerated Development in Sub-Saharan Africa: An Agenda for Action, The World Bank, Washington, D.C

The World Bank 2016. World development indicators (WDI). Washington, D.C: World Bank.

\section{Contributors:}

Ukwueze, Ezebuilo R. : This is the corresponding author, who wrote the introduction, the discussion and editing of the paper.

Ogbona, Oliver E.: He reviewed the literature with Urama, Chinasa $\mathrm{E}$.

Nwodo, Ozoemena S.: He wrote the methodology and ran the analysis

Urama, Chinasa E.: She reviewed the literature with Oliver Ogbonna 